\title{
Quality Assessment of Biodiesels Obtained from Pure Cooking Oils of Some Feedstocks and their Waste Oils
}

\author{
Irfan Khan ${ }^{1}$, Tariq Mahmood Ansari*1, Suryyia Manzoor ${ }^{1}$ and Muhammad Qasim ${ }^{2}$ \\ ${ }^{1}$ Institute of Chemical Sciences, Bahauddin Zakariya University, Multan, Pakistan. \\ ${ }^{2}$ HDIP, Petroleum Testing Centre, Multan, Pakistan. \\ *Corresponding Author Email: *tariqansari@bzu.edu.pk \\ Received 03 October 2017, Revised 17 August 2017, Accepted 30 November 2017
}

\begin{abstract}
Biodiesel being a renewable energy resource possesses compositional variability based on the type of feedstock. Biodiesel is considered a cleaner burning fuel and can be used as pure B100 or blended with petro-diesel. In this study, biodiesel was prepared from pure cooking oils (soybean oil, canola oil, sunflower oil, corn oil) and their waste frying oils by base-catalyzed transesterification with methanol in presence of sodium hydroxide. The optimized experimental parameters were applied to achieve the maximum yield of biodiesel. Various fuel properties like kinematic viscosity, flash point, pour point, cloud point, total acid number, specific gravity, water and sediments, conradson carbon residue, sulfur contents, phosphorous contents, sulphated ash, cetane and copper corrosion were determined and found comparable to ASTM standards. Pure cooking oils, their waste frying oils and prepared biodiesels were characterized by FT-IR. The study showed that the biodiesel derived from waste frying oils can be a promising alternative of the biodiesel from pure cooking oils.
\end{abstract}

Keywords: Pure cooking oils, Waste frying oils, Biodiesels, Physico-chemical properties, Environment.

\section{Introduction}

The need to explore new energy resources and the issues related to green house emission gases affecting the global climate has motivated the scientists to develop the pathways that can efficiently deal with energy crisis [1]. One such approach is the biodiesel production through different feed stocks that include vegetable oils and animal fats etc. According to ASTM 6751, biodiesel is defined as a renewable fuel consisting of mono-alkyl esters of long chain fatty acids obtained from vegetable oils and animal fats through transesterification in the presence of base as a catalyst [2-5]. During transesterification process, the vegetable oils (triglycerides) are allowed to react with lower alcohols most commonly methanol, in the presence of suitable catalyst $(\mathrm{NaOH}$ or $\mathrm{KOH})$. This reaction yields fatty acids methyl esters known as biodiesel along with a byproduct, called glycerol [6-7].
Biodiesel has received considerable attention as an alternative energy resource in the past few years due to its biodegradable, non toxic and environmental friendly nature [8-10]. Biodiesel also has high flash point, high $\mathrm{O}_{2}$ content (10-11\%) while low sulphur and aromatic contents [11]. All these characteristics lessen $\mathrm{SO}_{\mathrm{X}}, \mathrm{CO}$ and hydrocarbons emission. Biodiesel also does not participate in global warming because of its carbon closed cycle [12].

The use of edible oils like soybean, sunflower rapeseed etc. for biodiesel production has been a common practice in the early times; however, this may not be a preferable suggestion especially in the third world countries that are suffering from food crises [13]. As biodiesel is generally prepared from high quality vegetable oils, the prevalent cause of the elevated price tag 
problem is feedstock cost which is just about 70$90 \%$ of the whole cost of biodiesel synthesis [1415]. This issue may be solved by using the low cost feedstock i.e. waste frying oils. As compared to pure vegetable oils, cost of waste frying oils is $60 \%$ low because of its source and accessibility [16]. The exploitation of waste frying oil (WFO) may act as an efficient feedstock for the synthesis of biodiesel in order to make it economical, deal with the existing energy crisis and serious environmental pollution problems [17].

However, when the cooking oils are continuously heated at high temperatures, they undergo different degradation processes (hydrolysis, oxidation and polymerization) which may alter the physico-chemical properties of oils. The free fatty acid content of waste frying oils ranges between 10 to $25 \%$, which is due to heating in presence of air and light. This results in an increase in viscosity and specific heat [18]. Hence, their reuse can cause harmful effects on consumer's health. Secondly, their disposal is also of great concern to industries [19]. These alterations may affect the characteristics of the obtained biodiesel. The other parameters that may influence the biodiesel properties are the selection of different feedstocks [20-21]. Therefore, the study of various fuel parameters of the biodiesel synthesized from WFOs of known origins and their comparison with the biodiesels obtained from pure cooking oils is of utmost importance to determine their utility on commercial scale.

Our aim was to compare the fuel properties of biodiesels from pure cooking oils with the biodiesels of the respective WFOs. Hence for this purpose, four different oils were selected as feedstocks.

\section{Experimental Reagents}

Methanol, sodium hydroxide, potassium hydroxide, isopropyl alcohol, sodium sulphate, nhexane and zinc oxide were purchased from Merck (Germany), while hydrochloric acid, sulphuric acid and acetic acid were obtained from Riedel-de-Haen (Germany). Oxalic acid was bought from fluka
(Germany) and toluene from Aldrich (Germany). All the chemicals used were $>98 \%$ pure.

\section{Preparation of waste frying oils}

Four different types of WFOs i.e. waste canola oil (WCNO), waste sunflower oil (WSFO), waste soybean oil (WSBO) and waste corn oil (WCO) were prepared using their respective pure cooking oils (PCOs).

Firstly, $1 \mathrm{~kg}$ of the fish (Labeo rohita) was fried in one liter of pure sunflower oil in portions; each containing $250 \mathrm{~g}$ heated for 20 minutes. Hence, frying of $1 \mathrm{~kg}$ fish in one liter of the same oil consumed approximately 80 minutes. The same process was repeated for the rest of the three cooking oils to obtain respective WFOs.

\section{Pre-treatment of waste frying oils}

In order to evaporate the water contents, the waste frying oils were heated to a temperature of $120^{\circ} \mathrm{C}$ in a water bath. The temperature of reaction system was then lowered to $60^{\circ} \mathrm{C}$ and fried oils were filtered to remove the suspended particles and other impurities.

Preparation of Biodiesel from WFOs. The biodiesel was prepared by base catalyzed transesterification process. For this purpose, $6.5 \mathrm{~g}$ of sodium hydroxide in pellet form was weighed and added to $200 \mathrm{~mL}$ of methanol. The mixture was then heated by constant stirring for 1 hour on hot plate with magnetic stirrer to obtain sodium methoxide.

1 liter of each preheated WFOs was mixed with sodium methoxide solution and heated at $50{ }^{\circ} \mathrm{C}$ under continuous stirring at a fixed speed (250 rpm) for 90 minutes.

After transesterification reaction, the products of the reaction were exposed to open air to evaporate excess methanol for 40 minutes and transferred to separating funnel. The product mixture was left overnight which resulted in the appearance of two distinct liquid phases i.e. crude biodiesel at the top and glycerol phase at the 
bottom. The biodiesel was then collected for further studies.

The crude biodiesel was washed with deionized water $(4: 1 \mathrm{v} / \mathrm{v})$ three times to remove the residual by-products containing soap, glycerine, excess methanol and sodium hydroxide. The washed biodiesel was then dried using sodium sulphate, followed by filtration. Thus four types of biodiesels were obtained i.e. BWSFO, BWCNO, BWCO and BWSBO.

Preparation of biodiesel from pure cooking oil. The biodiesels i.e. BPSFO, BPCNO, BPCO and BPSBO from the pure cooking oils were also synthesized following the same procedure as described earlier for the purpose of comparison.

\section{FT-IR studies}

The pure cooking oils, their WFOs and the respective biodiesel samples were analyzed by Fourier Transform Infrared Spectroscopy (FT-IR). IR spectra from $4000 \mathrm{~cm}^{-1}$ to $400 \mathrm{~cm}^{-1}$ on alpha FT-IR, Bruker equipment in transmission mode.

\section{Analytical methods}

The analyses were performed according to the standards of the American Society for Testing and Materials (ASTM) in order to determine the various parameters of biodiesel.
The kinematic viscosity was determined by adopting the standard test method ASTM D 445. The standard test method ASTM D 1298 was applied for the laboratory determination of density, relative density and specific gravity of the biodiesel samples while ASTM D 93 was followed to determine the flash point. The acid constituents were calculated under the designation ASTM D 664. Cetane index formula was used to estimate the cetane number of biodiesel following ASTM D 613 and ASTM D, 976 while the cloud point was determined by using standard test method ASTM D 2500. The pour point was found under the designation ASTM D 97, whereas the standard method ASTM D 874 was applied for the determination of the sulfated ash in biodiesel.

\section{Results and Discussion FT-IR analysis}

IR spectroscopy is considered as one of the most significant modern analytical method for determining the formation of biodiesel from oils and fats [22]. FT-IR has been proved a successful technique for the detection of the functional groups in biodiesel and hence was used in this work. The PCOs and their WFOs presented similar spectral values (Fig. 1) as both had nearly the same chemical groups. However, their respective biodiesels presented some differences (Fig. 2).

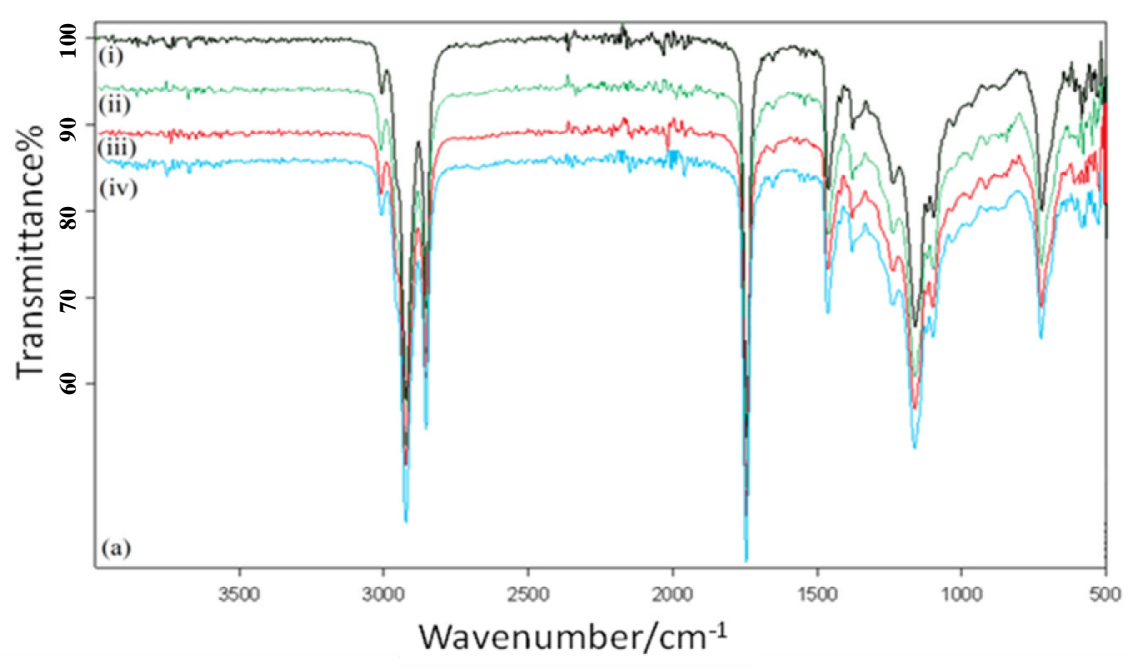




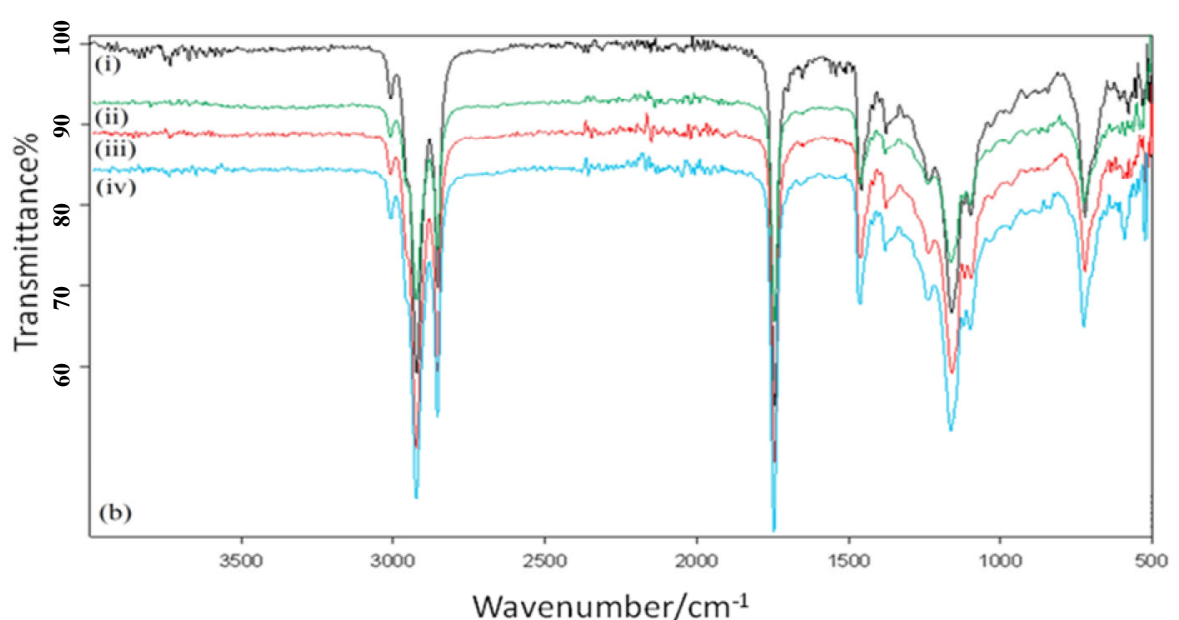

Figure 1. FTIR spectra of (a) pure cooking oils and (b) waste frying oils (i) Canola, (ii) Corn, (iii) Soybean, (iv) Sunflower
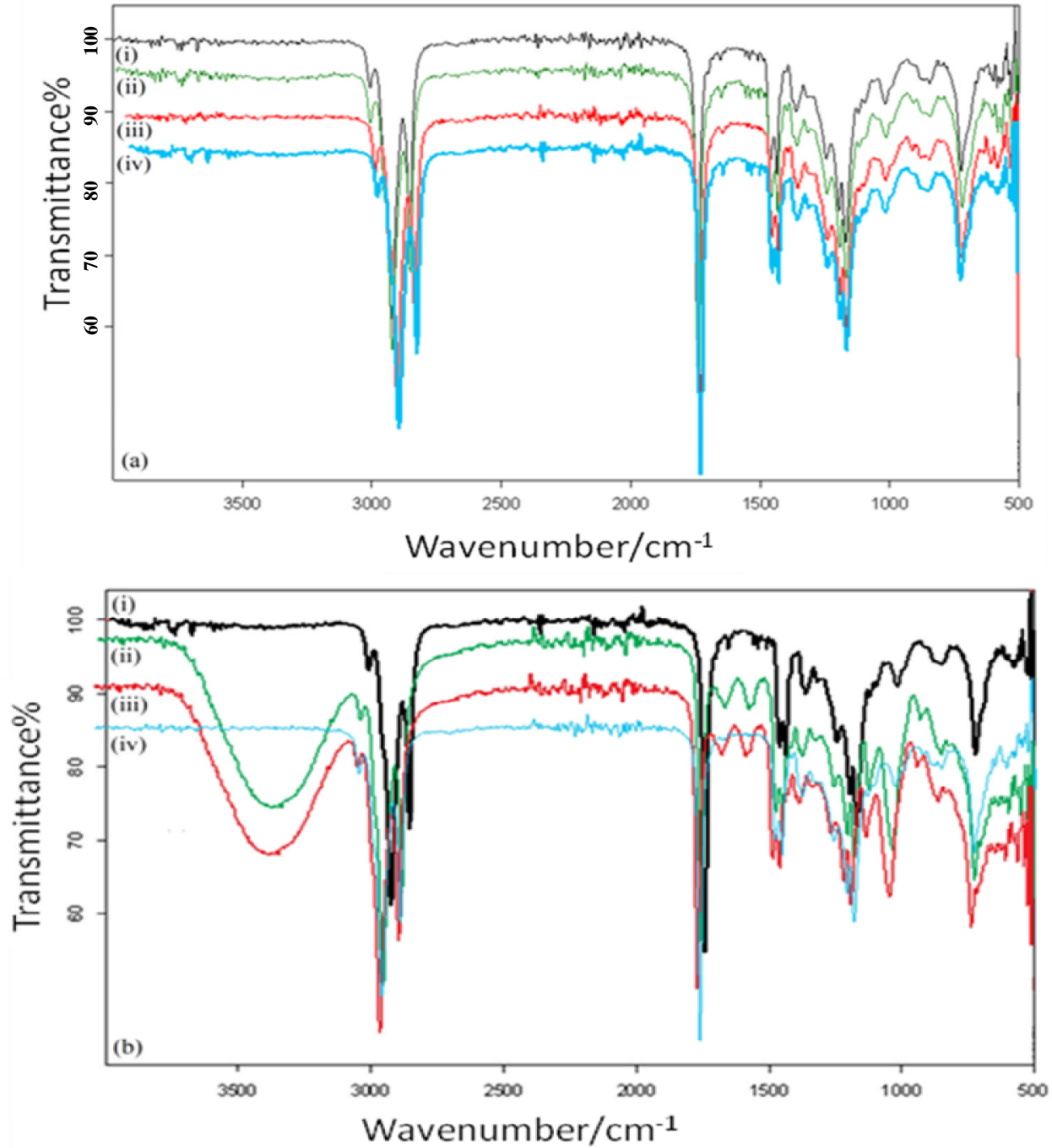

Figure 2. FTIR spectra of biodiesels from (a) pure cooking oils and (b) waste frying oils (i) Canola, (ii) Corn, (iii) Soybean, (iv) Sunflower 
The position of - $\mathrm{CO}$ band in FT-IR is affected by the substitutents. The methoxycarbonyl group in biodiesel showed a different band position of the -COOR vibration than in the PCOs and WFOs. Two strong absorption bands due to methoxy carbonyl and -C-O stretching were observed in all the esters.

The two most important bands appeared at $1195 \mathrm{~cm}^{-1}$ and $1435 \mathrm{~cm}^{-1}$ indicating the initial formation of $\mathrm{C}-\mathrm{O}$ and methyl ester $\left((\mathrm{CO})-\mathrm{O}-\mathrm{CH}_{3}\right)$ with its deformation vibration in FT-IR of all the biodiesels of PCOs and WFOs. The absence of these peaks in pure and waste frying oils confirmed the formation of biodiesels. Also the strong band of methoxy carbonyl group in biodiesel is at different position as compared to PCOs and WFOs.

\section{Physico-chemical properties}

The physico-chemical properties of biodiesel from PCOs and their WFOs were studied. All the biodiesels were characterized by determining kinematic viscosity, flash point, pour point, cloud point, total acid number, specific gravity, water and sediments, conradson carbon residue, sulphur contents, phosphorous contents, sulphated ash, cetane and copper corrosion. The results are shown in Table 1.

\section{Specific gravity}

The biodiesel is considered of superior quality when it has lower value of specific gravity [23]. The biodiesel from PCOs had specific gravity comparatively equal to biodiesels from WFOs. The BPCO and BWSFO had least values of specific gravity i.e. 0.8792 and 0.8810 correspondingly at $60 / 60{ }^{\circ} \mathrm{F}$.

\section{Flash point}

Flash point is a superlative quality parameter of biodiesel. A higher value of flash point minimizes the risk of fire [23]. The data regarding the flash point presented in Table 1 shows that the flash point of biodiesels obtained from WFOs was lower than PCOs. The presence of lower molecular weight compounds or volatile organic compounds produced during the frying process of oil, can be the probable cause of lower values of flash points of biodiesel obtained

Table 1. Physico-chemical properties of biodiesels prepared from pure and waste oils of different feedstocks.

\begin{tabular}{|c|c|c|c|c|c|c|c|c|c|c|}
\hline & \multirow{2}{*}{$\begin{array}{c}\text { Standard } \\
\text { methods } \\
\text { (ASTM) }\end{array}$} & \multicolumn{2}{|c|}{ Sunflower oil } & \multicolumn{2}{|c|}{ Canola oil } & \multicolumn{2}{|c|}{ Soybean oil } & \multicolumn{2}{|c|}{ Corn oil } & \multirow[b]{2}{*}{ Specifications } \\
\hline & & BPSFO & BWSFO & BPCNO & $B W C N O$ & BPSBO & BWSBO & BPCO & $B W C O$ & \\
\hline Specific Gravity at $60 / 60^{\circ} \mathrm{F}$ & D-1298 & 0.8839 & 0.8810 & 0.8820 & 0.8836 & 0.8810 & 0.8826 & 0.8792 & 0.8838 & - \\
\hline Flash Point (PMCC) $\left({ }^{\circ} \mathrm{C}\right)$ & D-93 & 160 & 116 & 146 & 118 & 159 & 152 & 167 & 156 & $130 \mathrm{~min}$. \\
\hline Cetane (Calculated) & D-976 & 54.5 & 56 & 55 & 57 & 56.0 & 54.5 & 57.5 & 57 & $47 \mathrm{~min}$. \\
\hline Pour Point $\left({ }^{\circ} \mathrm{C}\right)$ & D-97 & zero & -6 & -6 & -3 & -9 & -6 & -3 & -3 & - \\
\hline Cloud Point $\left({ }^{\circ} \mathrm{C}\right)$ & D-2500 & 6 & 3 & 3 & 6 & Zero & -3 & 3 & Zero & - \\
\hline Sulfur Contents (Wt \%) & IP-63 & 0.03 & 0.05 & 0.02 & 0.04 & 0.04 & 0.06 & 0.025 & 0.03 & $0.05 \max$ \\
\hline Sediment by Extraction (Wt \%) & D-473 & L 0.01 & L 0.01 & L 0.01 & L 0.01 & L 0.01 & L 0.01 & L 0.01 & L 0.01 & $0.05 \max$ \\
\hline Water contents (Vol. \%) & D-95 & L 0.05 & L 0.05 & L 0.05 & L 0.04 & L 0.05 & L 0.05 & L 0.05 & L 0.05 & $0.05 \max$ \\
\hline Copper Corrosion; $3 \mathrm{hrs}$ at $100^{\circ} \mathrm{C}$ & D-130 & $1 \mathrm{a}$ & $1 \mathrm{a}$ & $1 \mathrm{a}$ & $1 \mathrm{a}$ & $1 \mathrm{a}$ & $1 \mathrm{a}$ & $1 \mathrm{a}$ & $1 \mathrm{a}$ & 1a \\
\hline Conradson Carbon Residue (Wt \%) & D-189 & 0.03 & 0.04 & 0.03 & 0.04 & 0.020 & 0.037 & 0.01 & 0.04 & $0.05 \max$ \\
\hline Kinematic Viscosity at $40^{\circ} \mathrm{C}(\mathrm{cSt})$ & D-445 & 4.11 & 4.42 & 4.18 & 4.23 & 4.16 & 4.17 & 4.14 & 4.11 & $1.9-6.0$ \\
\hline Total Acid Number (mg KOH gm ${ }^{-1}$ ) & D-664 & 0.16 & 0.22 & 0.23 & 0.19 & 0.19 & 0.16 & 0.09 & 0.10 & $0.05 \max$ \\
\hline Phosphorous contents (Wt \%) & D-4951 & 0.0008 & 0.0008 & 0.0006 & 0.001 & 0.0008 & 0.0006 & 0.0010 & 0.0004 & $0.001 \max$ \\
\hline Sulphated Ash (Wt \%) & D-874 & 0.020 & 0.020 & 0.009 & 0.016 & 0.008 & 0.011 & 0.011 & 0.016 & $0.02 \max$ \\
\hline
\end{tabular}


from WFOs. Specifically analyzing each pair of biodiesels, we observed that the flash point values of BWSBO and BWCO were comparable to the biodiesels obtained from the PCOs. As WSBO and WCO showed better fuel parameters in terms of flash point, therefore, it can be suggested that the biodiesels, may be preferred over others.

\section{Pour point and cloud point}

The lower values of pour point and cloud point result in a better quality biodiesel [19]. Due to comparatively higher and than pure point cloud point is considered a better fuel [24]. The values of cloud point and pour point of biodiesels in this study were also in accordance with TM standards, however, the values of and of all the biodiesels showed variations from each other.

\section{Kinematic viscosity}

Viscosity affects the operation of fuel injection equipment. Biodiesel burns slowly in the engine if it has high viscosity which is due to low concentration of lighter components and hence results in more smoke [23]. The data obtained in this study showed that the biodiesels possessed kinematic viscosity in the range of 1.9-6.0 (cSt.) at $40^{\circ} \mathrm{C}$ and hence followed the standard values. Nevertheless, biodiesels from PCOs had lower kinematic viscosity values than biodiesels from respective WFOs and hence better fuel properties.

\section{Sulphur contents and copper corrosion}

The biodiesel from PCOs had lower sulphur and sulphated ash contents than WFOs but within the range of IP-63 and ASTM D 874 and hence more environmental friendly [23].

Copper strip corrosion values of all the biodiesel were also according to ASTM D 130 (1a max) ensuring that all the biodiesels are neutral [23].

\section{Carbon residues}

The biodiesel prepared from PCOs possessed lower carbon residues as compared to WFOs. Low carbon residue value suggested the presence of low concentration of aromatic compounds resulting in an improved quality biodiesel [23].

\section{Water contents}

The storage life of biodiesel is influenced by its oxidative stability which in turn is affected by the presence of water [25]. Therefore; it is an important parameter to be determined while analyzing the quality of biodiesel. All the biodiesel samples contained water contents less than 0.05 vol.\% (0.05 max) and sediment by extraction less than $0.01 \mathrm{wt} \%$ (0.05 max). The biodiesel is considered of better quality if it has no sediments and low water contents [25].

\section{Conclusion}

The quality parameters of biodiesels produced from WFOs and their respective PCOs have been studied in order to evaluate them as an alternate energy resource. The biodiesels obtained from PCOs presented better fuel properties in certain aspects than those obtained from WFOs as expected. Moreover, the values of different parameters obtained for biodiesels from WFOs of all feedstocks were also found in accordance with ASTM standards. The biodiesels from WFOs are also economically better than PCOs and hence are promising alternative feedstocks for the production of biodiesel. However, it must also be strongly emphasized that WFOs are very heterogeneous feedstock for the synthesis of biodiesel. These should be characterized in detail prior to conversion to biodiesels.

\section{Acknowledgement}

This manuscript is the outcome of Irfan Khan's M.Phil research work. Our gratitude goes to administration of "Institute of Chemical Sciences, Bahauddin Zakariya University, Multan, Pakistan" \& "HDIP Petroleum Testing Centre, Multan" in providing us the facilities required to carry out this research work.

\section{References}

1. M. R. Monteiro, A. R. P. Ambrozin, L.M. Lião, A. G. Ferreira, Talanta, 77 (2008) 593. https://doi.org/10.1016/j.talanta.2008.07.001. 
2. I. B. Banković-Ilić, I. J. Stojković, O. S. Stamenković, V. B. Veljkovic and Y. T. Hung, Renew. Sust. Energ. Rev., 32 (2014) 238. https://doi.org/10.1016/j.rser.2014.01.038

3. A. Demirbas, Energy Policy, 35 (2007) 4661. https://doi.org/10.1016/j.enpol.2007.04.003.

4. A. Woinaroschy, Fuel, 135 (2014) 393. https://doi.org/10.1016/j.fuel.2014.07.020.

5. G. Vicente, M. Martinez and J. Aracil, Bioresour. Technol. 98 (2007) 1724. https://doi.org/10.1016/j.biortech.2006.07.02 $\underline{4 .}$

6. D. A. G. Aranda, R. T. P. Santos, N. C. O. Tapanes, A. L. D. Ramos and O. C. Antunes, Catal. Lett., 122 (2007) 20.

https://doi.org/10.1007/s10562-007-9318-z.

7. A. Demirbas, Prog. Energy Combust. Sci., 31 (2005) 466.

https://doi.org/10.1016/j.pecs.2005.09.001.

8. B. R. Moser, In Vitro Cell. Dev. Biol., 45 (2009) 229.

https://doi.org/10.1007/s11627-009-9204-z.

9. X. Meng, M. Jia and T. Wang, Fuel., 121 (2014) 133.

https://doi.org/10.1016/j.fuel.2013.12.029.

10. W. T. Wazilewski, R. A. Bariccatti, G. I. Martins, D. Secco, S. N. M. De Souza, H. A. Rosa and L. I. Chaves, Ind. Crop Prod., 43 (2013) 207.

https://doi.org/10.1016/j.indcrop.2012.07.04 $\underline{6}$.

11. A. Demirbas, Energy Convers. Manage., 44 (2003) 2093.

https://doi.org/10.1016/S01968904(02)00234-0.

12. H. Fukuda, A. Kondo and H. Noda, J. Biosci. Bioeng., 92 (2001) 405.

https://doi.org/10.1016/S13891723(01)80288-7.

13. A. Samniang, C. Tipachan and S. Kajorncheappun-ngam, Renew. Energy., 68 (2014) 351.

https://doi.org/10.1016/j.renene.2014.01.039.

14. Z. Predojevic, Fuel, 17 (2008) 3522.

https://doi.org/10.1016/j.fuel.2008.07.003.
15. M. Canakci and H. Sanli, J. Ind. Microbiol. Biotechnol., 35 (2008) 431. https://doi.org/10.1007/s10295-008-0337-6.

16. M. Canakci, Bioresour. Technol., 98 (2007) 183.

https://doi.org/10.1016/j.biortech.2005.11.02 2 .

17. K. Khalisanni, K. Khalizani, M. S. Rohani and P. O. Khalid, Global J. Env. Res., 2 (2008) 81.

https://pdfs.semanticscholar.org/1a87/ccb20a bf7d8a1e992608802a421d57d3d4b2.pdf

18. Q. Zhang, C. Liu, Z. Sun, X. Hu, Q. Shen and J. Wu, Food Chem., 132 (2012) 1607. https://doi.org/10.1016/j.foodchem.2011.11.1 $\underline{29}$.

19. L. E. Rincón, J. J. Jaramillo and C. A. Cardona, Renew. Energy., 69 (2014) 479.

https://doi.org/10.1016/j.renene.2014.03.058.

20. S. K. Hoekman, A. Broch, C. Robbins, E. Ceniceros and M. Natarajan, Renew. Sustainable Energy Rev., 16 (2012) 143. https://doi.org/10.1016/j.rser.2011.07.143.

21. B. Salamatinia, A. Z. Abdullah and S. Bhatia, Fuel Process. Technol. 97 (2012) 1. https://doi.org/10.1016/j.fuproc.2012.01.003.

22. K. Dhanasekaran and M. Dharmendirakumar, Int. J. Curr. Res. Acad. Rev., 2 (2014) 105.

http://www.ijcrar.com/vol-

5/K.Dhanasekaran\%20and\%20M.Dharmendi rakumar.pdf.

23. G. Yasin, M. I. Bhanger, T. M. Ansari, S. M. S. R. Naqvi and F. N. Talpur, J. Pet. Technol. Altern. Fuels, 4 (2013) 53. doi: 10.5897/JPTAF12.025.

24. Y. Ali, M. A. Hanna and S. L. Cuppett, $J$. Am. Oil Chem. Soc., 72 (1995) 1557. https://doi.org/10.1007/BF02577854.

25. P. Berman, S. Nizri and W. Wiesman, Biomass Bioenerg., 35 (2011) 2861. https://doi.org/10.1016/j.biombioe.2011.03.0 $\underline{24}$. 